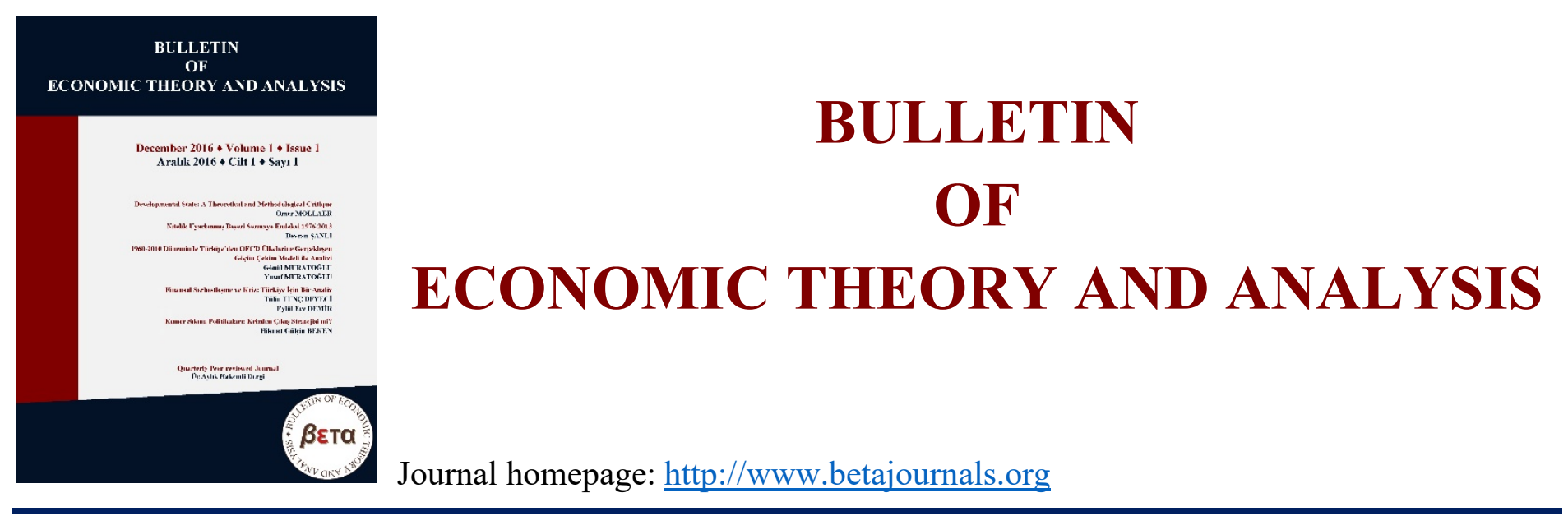

\title{
Petrol Fiyatları ve Döviz Kuru Arasındaki İlişkiye Asimetrik Bakış Açısı: Türkiye Örneği
}

Demet YAMAN ๑ 1 htps://orcid.org/0000-0002-9562-4320

To cite this article: Yaman, D. (2021). Petrol Fiyatları ve Döviz Kuru Arasındaki İlişkiye Asimetrik Bakış Açısı: Türkiye Örneği. Bulletin of Economic Theory and Analysis, 6(2), 155-170.

Received: 27 Oct 2021

Accepted: 30 Dec 2021

Published online: 31 Dec 2021

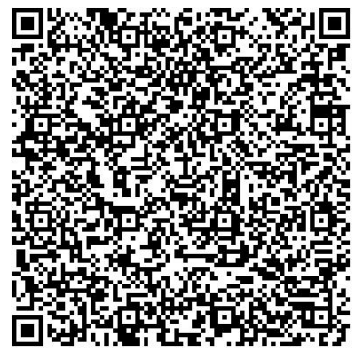

CAll right reserved 


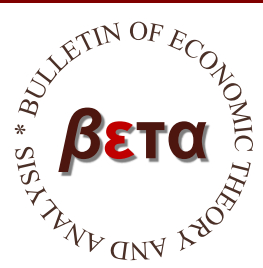

\title{
Bulletin of Economic Theory and Analysis
}

\author{
Volume VI, Issue 2, pp. 155-170, 2021 \\ http://www.betajournals.org
}

Original Article / Araştırma Makalesi

Received / Alınma: 27.10.2021 Accepted / Kabul: 30.12.2021

\section{Petrol Fiyatları ve Döviz Kuru Arasındaki İlişkiye Asimetrik Bakış Açısı: Türkiye Örneği*}

\author{
Demet YAMAN ${ }^{\mathrm{a}}$
}

${ }^{\mathrm{a}}$ Dr. Arş. Gör., Dicle Üniversitesi, İktisadi ve İdari Bilimler Fakültesi, İktisat Bölümü, Diyarbakır, TÜRKIYE 는 https://orcid.org/0000-0002-9562-4320

\section{öz}

Petrol fiyatları uluslararası piyasalarda hem anahtar fiyatlardan biri olarak hem de petrol dışındaki diğer enerji kaynakları için bir gösterge fiyat olarak kullanılmaktadır. Özellikle de Türkiye gibi gelişmekte olan, petrol ihracatçısı ülkelerde, bu önemli girdinin döviz kuru ile ilişkisi her dönem ilgi çekici bir araştırma konusu olmuştur. Bu çalışmada Türkiye'de petrol fiyatları ve nominal döviz kuru arasındaki ilişki 2 Ocak 2002-12 Ekim 2021 dönemi için, günlük veri seti kullanılarak (toplam 5161 gözlem) simetrik ve asimetrik nedensellik testleri ile incelenmektedir. Yapılan analizlerden elde edilen bulgular simetrik analizde değişkenler arasında karşıllklı bir nedensellik ilişkisinin varlığına işaret etmektedir. Asimetrik analizde ise hem pozitif hem de negatif bileşenlerde petrol fiyatlarından döviz kuruna doğru bir nedensellik olduğuna işaret etmektedir. Diğer taraftan, pozitif bileşenlerde döviz kurundan petrol fiyatlarına doğru nedensellik sadece istatistiksel olarak \%10 anlamlılık düzeyinde söz konusu iken, negatif bileşenlerde ise döviz kurundan petrol fiyatlarına doğru istatistiksel olarak $\% 5$ anlamlılık düzeyinde nedensellik ilişkisi olduğu görülmektedir.

Anahtar Kelimeler

Petrol Fiyatlar1, Nominal Döviz

Kuru, Nedensellik Analizi

JEL Kodu

C22, Q40

İLETIŞíiM Demet YAMAN $₫$ demet.yaman@dicle.edu.tr $\triangleq$ Dicle Üniversitesi, İktisadi ve İdari Bilimler Fakültesi, İktisat Bölümü, Diyarbakır, TÜRKIYYE

*Bu çalışma, ISEPA 2019'da sunulmuş olan “Türkiye'de Petrol Fiyatları ve Enflasyon Arasındaki Asimetrik İlişki" başlıklı bildirinin gözden geçirilmiş ve genişletilmiş halidir. 


\title{
Asymmetric Approach to the Relation Between Oil Prices and Exchange Rate: The Case of Turkey
}

\begin{abstract}
Oil prices are used in international markets both as one of the key prices and as an indicator price for other energy sources other than oil. Especially in developing oil exporter countries such as Turkey, the relationship of this important input to the exchange rate has been an interesting research topic every period.

In this study the relationship between oil prices and nominal exchange rate in Turkey is examined using a daily data set (total 5161 observations) using symmetric and asymmetric causality tests for the January 2, 2002 to October 12, 2021 period. The findings from the analyses indicate the existence of a mutual causality relationship between variables in symmetric analysis. In asymmetric analysis, it points out that there is a causality between oil prices and the exchange rate in both positive and negative components. On the other hand, causality from the exchange rate to oil prices in positive components is only statistically significant at the $10 \%$ significance level, while in negative components there is a causality relationship at the $5 \%$ significance level statistically from the exchange rate to oil prices.
\end{abstract}

Keywords

Oil Prices,

Nominal Exchange

Rate,

Causality Analysis

JEL Classification C22, Q40

\section{Giriş}

Günümüz ekonomilerinde, enerji, özellikle de petrol, üretimde kullanılan en temel girdilerden biri olarak karşımıza çıkmaktadır. Petrol fiyatları bu yönüyle uluslararası piyasalarda hem anahtar fiyatlardan biri olarak hem de petrol dışındaki diğer enerji kaynakları için bir gösterge fiyat olma niteliği taşımaktadır (Altıntaş, 2013: 2). Dünya nüfusunun hızla yükselmesi ve teknolojinin gelişmesiyle birlikte enerji tüketiminin de artması, bu sektörde oluşan gelişmelerin yakından izlenmesini zorunlu kılmaktadır (Yaylalı ve Lebe, 2012: 44).

Petrol ve petrol ürünleri, endüstriyel girdi olarak kullanımından itibaren reel ekonomi açısından giderek artan bir önem kazanmıştır. Özellikle bu durum, 1973 petrol krizinden sonra ülkeler açısından daha belirgin bir şekilde ortaya çıkmıştır. Petrol fiyatlarında son yıllarda sıkça rastlanan fiyat değişimleri onun potansiyel belirleyicilerine ve makroekonomik etkilerine odaklanılması gerekliliğini ortaya çıkarmıştır. Döviz kurları ise küresel düzeyde ekonomilerin rekabet gücüne ilişkin fikir sunmaktadır. Bu özelliklerinden dolayı döviz kurları ve petrol fiyatlarında yaşanan değişimler, oldukça önemli makroekonomik ve finansal sonuçlar doğurabilmektedir. 
Petrol fiyatları ile döviz kurları arasındaki bağlantıyı araştıran çok sayıda teorik ve ampirik araştırma vardır, ancak sonuçlar konusunda bir görüş birliği olmaması nedeniyle net bir yaklaşım benimsemek güçtür. Teorik açıdan bakıldığında, petrol fiyatları döviz kurları arasındaki ilişki, birden fazla kanal üzerinden çalışabilir. (Huang ve diğ; 2021: 720). Petrol fiyatlarının döviz kurları üzerindeki etkisini açıklamada; dış ticaret hadleri kanalı ve servet etkisi kanalı öne çıkmaktadır. Dış ticaret hadleri kanalı, petrol fiyatının ticaret koşullarını etkileyen çevresel bir rol oynadığını vurgulamaktadır. Amano ve van Norden (1998), ticarete konu olan ve olmayan mallar için basit iki sektörlü bir model oluşturmakta ve petrol fiyatlarının döviz kurlarındaki kalıcı şokların önemli bir nedeni olduğunu göstermektedir. Dış ticaret hadleri kanalı yaklaşımına göre, bir ülke ekonomisi ithal edilen petrole diğer bir ülkeye göre daha bağımlı ve bu ülkede ticarete konusu sektörler diğer sektörlere (ticaret konusu olmayan) göre petrol fiyatlarındaki değişimlere daha duyarlı ise petrol fiyatlarındaki bir artış bu ülkenin para biriminin diğer ülkenin para birimine göre reel anlamda değer kazanmasına yol açabilmektedir. Tam tersi durumda geçerlidir.

Servet etkisi kanalı için ise, Golub (1983) ve Krugman (1983), petrol fiyat hareketinin petrol ithalatçısından petrol ihraç eden ülkelere servet transferi ile sonuçlandığını belirtmek için teorik bir temel oluşturmaktadır. Bu yaklaşıma göre petrol fiyatlarındaki artış servetin, petrol ithalatçısı konumunda olan ülke ekonomisinden, petrol ihracatçısı konumundaki ülke ekonomisine doğru transfer edilmesine yol açarak, petrol ihracatçısı ülkenin cari işlemler dengesini pozitif biçimde etkileyecektir. Bu durum petrol ihraç eden ülkenin para biriminin değer kazanmasına neden olabilecektir. Petrol ithalatçısı ülkenin ise cari işlemler dengesi negatif yönde etkilenerek ve ülkenin para birimi değer kaybedebilecektir.

Öte yandan, döviz kurlarının petrol fiyatlarındaki değişimleri açıklamadaki potansiyel önemi de teorik olarak araştırılmaktadır. Bloomberg ve Harris (1995) çalışmalarında tek fiyat yasasına dayanarak, döviz kurlarının petrol fiyatları üzerindeki etkileri hakkında bazı yararlı bilgiler sunmaktadır. Ham petrolün uluslararası olarak ABD doları cinsinden işlem gören birincil enerji kaynağı olduğu göz önüne alındığında, doların değer kaybetmesi, uluslararası alıcılara maliyeti düşürmekte, petrole olan talebi arttırmakta ve yaşanan talep artışı petrol fiyatlarının yeniden yükselişe geçmesine neden olabilmektedir.

2008 Küresel Finans Krizi sonrası hem OPEC'in petrol fiyatı üzerindeki belirleyiciliğinin azalması ve oluşan küresel riskler nedeniyle petrol fiyatlarının oynaklı̆̆ı artmış ve öngörülebilirliği 
azalmıştır. Petrol fiyatlarının yüksek seyir izlemesi, Türkiye gibi net ithalatçı durumundaki bir ülke için girdi maliyetlerinin artması anlamına gelmektedir. Bu durum ülkeden döviz çıkışına neden olarak dış açıkların artmasına ve üretim maliyetlerinin yükselmesine neden olarak ihracatta ülkenin rekabet gücünün zayıflamasına neden olmaktadır. $\mathrm{Bu}$ nedenle, petrol fiyatı ile döviz kuru arasındaki ilişki enerjide dışa bağımlı olan Türkiye için ciddi bir önem teşkil etmektedir (Dücan ve Şentürk, 2017: 29).

Özellikle gelişmekte olan ülkelerin, petrol ithali yapan gelişmiş ülkelerle kıyaslandıklarında enerjiye daha çok bağımlı olmaları ve bu enerjinin yoğun olarak kullanıldığı sektörlere sahip olmaları nedeniyle petrol fiyatlarındaki değişmelerden ciddi oranda etkilenebilmektedir. Örneğin, petrol fiyatlarında meydana gelen bir artış durumunda; firmalar enerji taleplerini düşürmekte ve daha az enerji satın almaktadır. Buna bağlı olarak faktör (sermaye ve emek) verimliliği azalarak, milli gelirin düşmesine neden olabilmektedir. Petrol fiyatındaki artışlar, aynı zamanda piyasada belirsizlik ortamı oluşturarak, makro ekonomik faaliyetler üzerinde dolaylı etkiler ortaya çıkarabilecektir.

Literatürde petrol fiyatı ile döviz kuru arasındaki ilişkiye yönelik çalışmalar yapılmış ancak bu çalışmalar incelendiği dönem ve ülkeye göre birbirinden farklı sonuçlara ulaşmıştır. Bu yönüyle de gelişen yöntemlerle petrol fiyatları ve döviz kuru ilişkisi halen araştırılmaya devam etmektedir. Bu bağlamda çalışmanın amacı Türkiye'de petrol fiyatları ve nominal döviz kuru arasındaki ilişkiyi, esnek döviz kuru sistemine geçilen 2 Ocak 2002 ve 12 Ekim 2021 dönemi için, günlük veri seti kullanılarak (toplam 5161 gözlem) simetrik ve asimetrik nedensellik testleri ile incelenmektedir. Çalışma, analizde kullanılan yöntem ve güncel verilere dayalı olarak yapılması itibariyle mevcut literatüre katkı sağlayabilecek niteliktedir. Bu yönüyle çalışmada Türkiye'de nominal döviz kuru ve petrol fiyatları arasındaki ilişkiye güncel bir bakış açısı kazandırmak amaçlanmaktadır. Çalışmanın giriş bölümünü izleyen ikinci bölümünde literatürde yer alan çalışmalardan bazı örneklere yer verilmiştir. Üçüncü bölümde analizde kullanılan veri seti ve yöntem tanıtılmıştır. Dördüncü bölümde ekonometrik analizden elde edilen bulgular paylaşılmıştır. Sonuç bölümünde ise, bulgular çerçevesinde genel bir değerlendirme yapılıp, politika önerilerine yer verilmiştir. 


\section{Yazın Taraması}

Literatür incelendiğinde petrol fiyatları ve döviz kuru ilişkisine yönelik uygulamalı çalışmaların geniş biçimde ele alınmakla birlikte, yapılan çalışmalar ülke/ülke grupları, kullanılan yöntemler ve sonuçları bakımından birbirlerinden farklılıklar göstermektedir.

Fasanya vd. (2021) çalışmalarında; Ocak 1997 ile Aralık 2019 arasındaki aylık verileri kullanarak Nijerya için petrol fiyatı ile döviz kuru arasındaki ilişkiyi asimetrik ARDL yöntemiyle incelemişlerdir Bulgulara göre ilk olarak, petrol fiyatlarındaki artış, Naira'nın ABD dolarına göre değer kaybetmesine neden olmuştur. Bunun yanında petrol ve döviz kuru piyasalarında 2000 ABD Irak işgaline, 2005 Asya talebinin yükselişine, 2008 küresel mali krizine ve 2015 Arap kaynaklarına denk gelen yapısal kırılmalar olduğuna dair kanıtlara işaret etmektedir. Son olarak, yapısal kırılmaların ve asimetrinin göz ardı edilmesinin ciddi önyargılara ve yanıltıcı sonuçlara yol açacağ 1 tespit edilmiştir.

Huang vd. (2021) çalışmalarında, Ocak 1997 - Temmuz 2015 dönemine ait reel petrol fiyatları ve reel döviz kurlarının aylık verilerini alarak 81 ülkeyi net petrol ithalat durumlarına göre sınıflandırmışlardır. Buna göre serbest dalgalanan kur sistemlerini benimseyen ülkeler için petrol ithalatçıları önemli ölçüde negatif çift yönlü korelasyon gösterirken, petrol ihracatçıları petrol fiyatları ile döviz kurları arasında korelasyon göstermemektedir. Yönetilen dalgalı sistemlerde ise petrol ithalatçıları veya ihracatçıları için, döviz kurları petrol fiyatları için öngörü niteliği taşımaktadır. Bu ilişkilerin bilinmesi, ham petrol fiyatı ve döviz kuru hareketlerinden kaynaklanan ani ve önemli şokları önlemek için hükümet politikasının geliştirilmesine rehberlik edebileceği vurgulanmaktadir.

Öztürk ve Cavdar (2021) çalışmalarında, Çin ekonomisinde COVID-19 pandemisinin döviz kuru, petrol fiyatları, altın ve bitcoin üzerindeki etkisini 2 Eylül 2019- 20 Aralık 2020 dönemi için günlük veriler kullanarak, ARMA- EGARCH yöntemiyle araştırmaktadırlar. Bulgular, incelenen dönemde altın, döviz kurları, petrol fiyatları ve bitcoinin pandemi sırasında çok değişken olduğu ve Covıd-19'un değişkenlerin koşullu değişkenliği üzerinde istatistiksel olarak anlamlı etkileri olduğu tespit edilmiştir.

Gül vd. (2021) çalışmalarında, Rusya ekonomisi için, petrol fiyatları ve döviz kuru rejimi arasındaki ilişkiyi 1994-2018 dönemi için üçer aylık veriler kullanarak Modifiye Vektör Otoregresif (VAR) model kullanarak incelemektedir. Analizlerden elde edilen bulgular, yerli 
paranın (ruble) aşırı değer kazanmasının ve petrol fiyatlarında yaşanan ani artışların faiz oranını, serbest dalgalanan kur rejiminin benimsendiği durumdan daha çok düşürdüğüne, fiyatların ise dalgalı kur rejiminin benimsendiği durumdan daha çok düştüğüne işaret etmektedir.

Büberkökü (2021) çalışmasında, reel döviz kuru ve reel petrol fiyatları arasındaki ilişkinin varlığını, 14 gelişmiş ve 20 gelişmekte olan ülke, 1999: M1- 2016: M6 dönemi için aylık veriler yardımıyla, Panel nedensellik testleri ile araştırmaktadır. Elde edilen bulgular, hem gelişmiş hem de gelişmekte olan ülkelerde değişkenler arasında karşılıklı bir nedensellik ilişkisi olduğunu doğrulamaktadır.

Kisswani vd. (2019) çalışmalarında, seçilmiş Asya ülkelerinde petrol fiyatları ve döviz kuru arasındaki asimetrik ilişkiyi, 1970:Q1- 2016:Q4 dönemi için, doğrusal olmayan ARDL (NARDL) yaklaşımıyla incelemektedir. . Makale ayrıca, Toda ve Yamamoto nedensellik testini kullanarak petrol fiyatı-döviz kuru arasındaki nedensellik ilişkisinin yönünü de araştırılmaktadır. Ampirik sonuçlar, yapısal kırılmalar dikkate alındığında, sadece Endonezya ve Malezya için uzun vadeli asimetri ilişkiye işaret etmektedir. Bunun yanında petrol fiyatı ile döviz kuru arasında bazı ülkelerde çift yönlü bir nedensellik bulunurken, bazılarında ise tek yönlü bir nedensellik olduğu görülmekte olduğundan, nedensellik testi bulgularının karmaşık olduğu söylenebilir.

Lv vd. (2018) çalışmalarında, 17 petrol ihracatçısı ülkeyi döviz kuru rejimlerine göre üç gruba ayırarak, 2000:1- 2015:12 dönemi için aylık veriler kullanarak, döviz kurları ve petrol fiyatları arasındaki doğrusal olmayan çift yönlü dinamik ilişkiyi Markov rejim değiştirme vektör otoregresyon (MS-VAR) modeli (veya vektör hata düzeltme modelini (MS-VECM)) yardımıyla analiz etmektedir. Bulgular serbest dalgalı döviz kuru sistemlerine sahip ülkelerin petrol fiyatları ile döviz kurları arasında anlamlı derecede negatif çift yönlü korelasyon olduğunu göstermektedir. Ayrıca, petrol fiyatları ile döviz kurları arasındaki korelasyonun yüksek hükümet kısıtlamaları ile zayıfladığı da vurgulanmaktadır. Bununla birlikte, yönetilen dalgalı döviz kuru sistemleri veya sabitlenmiş döviz kuru sistemleri için her iki yöndeki ilişkinin varlığının tam olarak göz ardı edilemeyeceği ifade edilmektedir.

Ağazade (2018) çalışmasında, Azerbaycan ekonomisinde, reel döviz kuru ve petrol fiyatları arasındaki asimetrik ilişkiyi 1995:01-2017:09 dönemi için TAR ve MTAR kointegrasyon yöntemiyle incelemektedir. Yapılan analizlerden elde edilen bulgular, incelenen dönemde 
Azerbaycan ekonomisinde reel döviz kurunun reel petrol fiyatlarına asimetrik şekilde uyarlanmasını destekleyici nitelikte zayıf bulgular sunmaktadır.

Adıgüzel vd. (2016) çalışmalarında, Türkiye'de reel petrol fiyatları ve reel döviz kuru arasındaki olası bir asimetrik ilişkinin varlığını, 2009: M1- 2015: M12 dönemi için aylık veriler kullanarak Hatemi-J ve Roca (2014) tarafından geliştirilen asimetrik nedensellik testi ile incelemektedirler. Yapılan analizler sonucunda incelenen dönemde petrol fiyatlarından döviz kuruna doğru bir asimetrik bir nedensellik ilişskisi olduğu tespit edilmiştir.

Y1lmaz ve Altay (2016) çalışmalarında, Türkiye'de döviz kurunda yaşanan değişimlerin ham petrol fiyatlarını ne yönde etkilediği, 1985-2015 dönemine ait aylık veriler kullanılarak, ARDL eşbütünleşme yaklaşımıyla incelenmektedir. Analizlerden elde edilen bulgular, incelenen dönemde değişkenler arasında eşbütünleşme ilişkisi tespit edilmiştir. Ayrıca sonuçlar, petrol fiyatlarından döviz kurlarına doğru, oynaklık yayılma etkisinin varlığına işaret etmektedir.

Bal ve Rath (2015) çalışmalarında, döviz kuru ve petrol fiyatları arasındaki ilişkiyi, Hindistan ve Çin ekonomileri için, Hiemstra ve Jones (1994)' un doğrusal olmayan Granger nedensellik testini VAR kalıntılarına uygulayarak incelemişlerdir. Çalışma, her iki ülkede de petrol fiyatları ile döviz kurları arasında anlamlı bir çift yönlü doğrusal olmayan Granger nedenselliği bulmaktadır. Bulgular, petrol fiyatının doğrusal olmayışının döviz kuru rejimlerinden bağımsız olarak kurları etkilediğini göstermektedir. Ayrıca, sağlamlığı kontrol etmek için, bir GARCH (1, 1) modeli kullanılarak petrol fiyatı ve döviz kuru varyansındaki kalıcılık dikkate alınır. Sonuçlar Hindistan örneğinde tutarlı bir şekilde devam ederken, Çin ile ilgili olarak, tek yönlü bir nedensellik döviz kurundan petrol fiyatına doğru uzanmaktadır. Bununla birlikte, Çin'deki petrol fiyatının döviz kurunun Granger nedeni olmadığ ifade edilmektedir.

Tiwari ve Albulescu (2016) çalışmalarında, Hindistan ve ABD ekonomilerinde petrol fiyatları döviz kuru arasında 1980: M1- 2016: M2 dönemi için, aylık verileri kullanarak, sürekli dalgacık ve asimetrik nedensellik testi ile, değişkenler arasındaki ampirik ilişkiler araştırılmaktadır. Bulgular, döviz kurunun uzun vadede petrol fiyatına neden olduğunu gösterirken, kısa vadede bunun tersinin geçerli olduğu görülmüştür. Buna ek olarak sonuçlar, değişkenler arasındaki Granger-nedensel ilişkinin doğrusal olmayan, asimetrik ve dolaylı olduğunu, bu durumun politika yapıcıların ve firmaların daha iyi stratejik ve yatırım kararları almalarına yardımcı olacağını göstermektedir. 
Altıntaş (2013) çalışmasında, Türkiye'de petrol fiyatları, reel döviz kuru ve ihracat arasındaki ilişkiyi 1987-2010 dönemi için, üç aylık veriler kullanarak ARDL sınır testi ve dinamik nedensellik testi yaklaşımıyla incelemektedir. Analizlerden elde edilen bulgular, incelenen dönemde reel döviz kuru artışının ihracatı azalttığı, reel petrol fiyatındaki artıştan ise ihracatın etkilenmediği görülmüştür.

Reboredo ve Rivera-Castro (2013) çalışmalarında, Euro bölgesi ülkelerinde, 4 Ocak 2000 ve 7 Ekim 2011 dönemi için günlük veriler yardımıyla petrol fiyatları ve döviz kuru arasındaki ilişki dalgacık çoklu çözünürlük (Wavelet multi resolution) yöntemi ile analiz edilmiştir. Elde edilen bulgular, kriz öncesi dönemde petrol fiyatlarının ve döviz kurlarının ilişkili olmadığını göstermektedir. Buna ek olarak, kriz döneminde petrol fiyatları ile kurların ilişkili olduğu görülmüştür. Bu bulguların risk yönetimi, enflasyonist baskıları kontrol altına almak için para politikaları ve petrol ihraç eden ülkelerdeki politikası üzerinde önemli etkileri bulunduğu ifade edilmektedir.

Yaylalı ve Lebe (2012) çalışmalarında, Türkiye'de ithal ham petrol fiyatlarının fiyatlar genel düzeyi başta olmak üzere makroekonomik göstergeler üzerindeki etkisini, 1986Q2-2010Q2 dönemini için üçer aylık veriler kullanarak VAR yöntemiyle analiz etmişlerdir. Sonuçlar, ithal ham petrol fiyatlarının para arzı üzerinde etkili olduğu ve enflasyonun önemli bir kaynağı olduğunu göstermektedir.

Chen ve Chen (2007) çalışmalarında, G7 ülkelerinde reel döviz kuru ve reel petrol fiyatları arasındaki uzun dönemli ilişki, 1972:1-2005:10 dönemi için aylık veriler yardımıyla, panel veri analizi teknikleri ile incelenmektedir. Elde edilen bulgular, reel petrol fiyatlarının reel döviz kuru hareketlerinin baskın kaynağı olabileceğini ve reel petrol fiyatları ile reel döviz kurları arasında bir bağlantı olduğu göstermiştir. Panel regresyon tahminleri, reel petrol fiyatlarının, reel döviz getirilerini tahmin etme açısından önemli bir güce sahip olduğunu göstermektedir.

Yukarıda literatürde döviz kurları ve petrol fiyatları arasındaki ilişkiyi inceleyen çalışmalardan bazı örneklere yer verilmiştir. Bu çalışmalardan hem Türkiye hem de çeşitli ülke ve ülke grupları için yapılan analizlerden elde edilen sonuçlar incelendiğinde, söz konusu iki değişken arasındaki ilişkinin varlığı ve yönü konusunda bir görüş birliğine ulaşılamadığı söylenebilir. Dolayısıyla gelişen yöntem ve tekniklerle döviz kuru ve petrol fiyatı ilişkisi farklı ülkeler ve dönemler için incelenmeye devam edilmektedir. 


\section{Veri Seti ve Ekonometrik Metodoloji}

Çalışmanın ampirik analiz kısmında 2 Ocak 2002 - 12 Ekim 2021 dönemini kapsayan günlük veriler kullanılmıştır. Döviz kuru değişkeni için nominal döviz kuru (DK), petrol fiyatlarına (PF) ait veriler için Avrupa Brent Petrol (varil başına dolar) fiyatları kullanılmıştır. Veri setinde yer alan değişkenler, Türkiye Cumhuriyet Merkez Bankası (TCMB) elektronik veri dağıtım sisteminden (EVDS) elde edilmiş olup, ekonometrik analizler EViews 12.0 ve Gauss 9.0 paket programları kullanılarak gerçekleştirilmiştir.

\section{DK}

10

9

8

7

6

5

4

3

2 1

$\begin{array}{llllllllll}02 & 04 & 06 & 08 & 10 & 12 & 14 & 16 & 18 & 20\end{array}$




\section{PF}

160

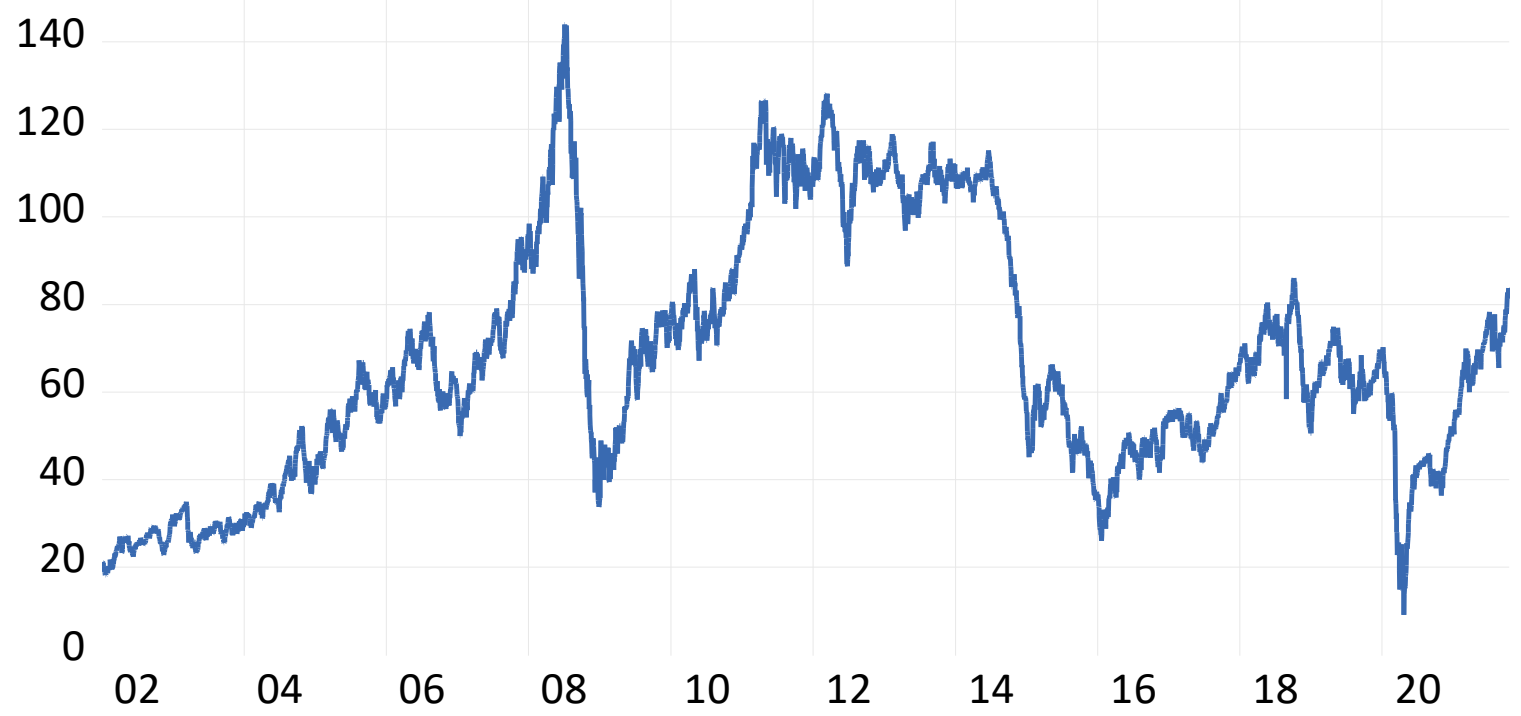

Şekil 1. İncelenen Dönemde Nominal Döviz Kuru ve Petrol Fiyatları Serisinin Seyri

Şekil 1'deki döviz kuru serisi incelendiğinde, serinin 2002-2008 yılları arasında yatay bir seyir izlediği görülmektedir. 2008 küresel krizi ile birlikte kur fiyatlarında ciddi oynaklıklar gözlenmeye başlamıştır. 2014 yılı itibariyle ulusal ve uluslararası ekonomide yaşanan gelişmeler neticesinde kurda önemli artışlar olduğu görülmektedir. Türkiye'de yaşanan darbe girişimi, Ağustos 2018'de yaşanan kur şoku, 2020 yılından itibaren gündeme gelen Covid-19 salgını ve son yıllarda para politikasında yaşanan belirsizliklerin döviz kurlarına yansıdığı söylenebilir.

Petrol fiyatları serisine bakıldığında ise 2008 küresel krizine kadar petrol fiyatlarında artı̧̧ olduğu görülmektedir. 2008 küresel krizinin etkisiyle fiyatlarda düşme eğilimi olduğu göze çarpmaktadır. 2010 yılından sonra Ortadoğu ülkelerini etkisi altına alan Arap Baharı ile birlikte petrol fiyatları yeniden artış göstermiş̧ir. 2014-2016 yıllarında ise petrol fiyatlarında keskin düşüşler gözlenmiştir. Bunun birkaç nedeni vardır. Bu nedenlerden ilki Çin'deki ekonomik büyüme hızının yavaşlamış olması nedeniyle enerji talebinin azalması, ikincisi Amerika'nın kendi petrolünü üretmesi ve ihraç edecek duruma gelmesidir. Son olarak da Rusya ve Suudi Arabistan'ın petrol arzını kısmak istememesi fiyatların düşmesine neden olmuştur. 16 Ocak 2016 tarihinde Rusya ve Suudi Arabistan petrol bakanlarının anlaşmaları sonucunda petrol arzı sabit tutulmaya başlanmış ve bu tarihten itibaren dünya petrol fiyatlarında artışlar görülmüştür. 2020 yılında 
küresel bir salgın haline gelen Covid-19 ile birlikte 2020 yılının başlarında petrol fiyatları alınan kısıtlama ve karantina önlemleri ile birlikte ele alınan dönemde en düşük seviyelerinde ulaşmıştır.

Çalışmada serilerin durağanlığı Genişletilmiş Dickey-Fuller (ADF) ve Phillips-Perron (PP) birim kök testleri aracılığıyla araştırılmıştır. Çalışmada simetrik ve asimetrik nedensellik testlerinden yararlanılmış olup simetrik testte Hacker ve Hatemi-J (2006) tarafindan önerilen Boostrapt Temelli Toda-Yamamoto Nedensellik Testi'nden yararlanılmıştır. Söz konusu bu test Toda-Yamamoto (1995) tarafından önerilen nedensellik testine dayanmaktadır. Testin en önemli, özelliği değişkenlerin durağan olmadığı durumlarda serinin farkının alınmadan analize dâhil edildiği için serilerde bilgi kaybına neden olmamasıdır. Toda-Yamamoto (1995) değişkenlerin gecikme değerlerini içeren genişletilmiş VAR modeli geliştirilmişlerdir. $V A R(p)$ modeli aşağıda verilmiştir.

$$
Y_{t}=v+A_{1} y_{t-1}+\cdots+A_{p} y_{t-p}+\varepsilon_{t}
$$

Eşitlikte, $y_{t}, v$ ve $\varepsilon_{t} n$ boyutlu vektörleri; $A_{r}, n x n$ boyutlu $r$ mertebesinde gecikme uzunluğuna göre belirlenen parametre matrisini göstermektedir. Değişkenler bütünleşik olduğunda Toda-Yamamoto (1995) aşağıdaki eşitlikte yer alan $V A R(p+d)$ modelini önermektedirler:

$$
Y_{t}=\hat{v}+\widehat{A}_{1} y_{t-1}+\cdots+\widehat{A}_{p} y_{t-p}+\cdots+\widehat{A}_{p+d} y_{t-p-d}+\widehat{\varepsilon}_{t}
$$

Eşitlikte $d$ maksimum bütünleşme derecesini ifade etmektedir. Model aşağıdaki eşitlikteki gibi k1saltılabilir:

$$
\mathrm{Y}=\widehat{\mathrm{D}} \mathrm{Z}+\widehat{\delta}
$$

Bu modeli açarsak:

$$
\begin{aligned}
& Y:=\left(y_{1}, \ldots, y_{T}\right),(n x T) \text { matrisidir, } \\
& \widehat{D}:=\left(\widehat{v}, \widehat{A}_{1}, \ldots, \widehat{A}_{p}, \ldots, \widehat{A}_{p+d}\right),(n x(1+n(p+d))) \text { matrisidir. } \\
& Z_{t}:=\left[\begin{array}{c}
1 \\
Y_{t} \\
Y_{t-1} \\
\vdots \\
Y_{t-p-d+1}
\end{array}\right],((1+n(p+d)) x 1) \text { matrisidir. }
\end{aligned}
$$




$$
\begin{aligned}
& \mathrm{Z}:=\left(\mathrm{Z}_{0}, \ldots, \mathrm{Z}_{\mathrm{T}-1}\right), \operatorname{bir}((1+\mathrm{n}(\mathrm{p}+\mathrm{d})) \times \mathrm{T}) \text { matrisidir. } \\
& \hat{\delta}:=\left(\hat{\varepsilon}_{1}, \ldots, \hat{\varepsilon}_{\mathrm{T}}\right),(\mathrm{nxT}) \text { matrisidir. }
\end{aligned}
$$

Toda-Yamamoto (1995) nedensellik testinde sifir hipotezi "Granger nedeni değildir" önermesini sınamaktadır. Bu sıfır hipotezini sınamak için aşağıdaki eşitlikte yer alan MWALD testini önermişlerdir:

$$
\operatorname{MWALD}=(\mathrm{C} \widehat{\beta})^{\prime}\left[\mathrm{C}\left(\left(\mathrm{Z}^{\prime} \mathrm{Z}\right)^{-1} \oplus \mathrm{S}_{\mathrm{U}}\right) \mathrm{C}^{\prime}\right]^{-1}(\mathrm{C} \widehat{\beta})
$$

Eşitlikte yer alan $\bigoplus$; kronecker çarpanını; $S_{U}(3)$ numaralı eşitlikteki modelin hata teriminin varyans-kovaryans matrisini; $C, \operatorname{pxn}(1+\mathrm{n}(\mathrm{p}+\mathrm{d}))$ matrisini ifade etmektedir. MWALD test istatistiği asimptotik olarak $\chi^{2}$ dağılımına sahiptir ve hata teriminin normal dağıldı̆̆ varsayılmaktadır.

Hacker ve Hatemi-J (2006) hata teriminin otoregresif koşullu değişen varyans (ARCH) ve normal dağılmama özelliklerine sahip olduğu durumlarda MWALD test istatistiğinin sıfır hipotezini reddetme yönünde yanlı sonuçlar vereceğini göstermişlerdir. $\mathrm{Bu}$ durumda bootstrap dağılımının kullanılması gerektiğini belirtmişlerdir. Bu çerçevede MWALD test istatistiği farklı durumlarda bile gerçek değerine yakınsamaktadır.

Granger ve Yoon (2002), değişkenler arasındaki ilişsinin pozitif ve negatif şoklar için ayrı ayrı incelendiğinde farklılaşabileceğini ifade etmiştir. Hatemi-J (2012) Granger ve Yoon (2002)’ye dayanarak pozitif ve negatif şokların nedensellik ilişkisinde de farklılaşabileceğini belirtmiş ve Asimetrik Nedensellik Testi'ni geliştirmiştir. Bu kapsamda, Hatemi-J (2012) pozitif ve negatif bileşenler için simetrik nedensellik analizinde gösterilen süreç ayrı ayrı gerçekleştirilerek Asimetrik Nedensellik Testi sonuçlarının elde edilebileceğini ifade etmiştir.

\section{Bulgular}

Çalışmada, Türkiye' de petrol fiyatları ve nominal döviz kuru arasındaki ilişki, zaman serisi analiz tekniklerinden simetrik ve asimetrik nedensellik testleri kullanılarak araştırılmıştır. Bu kapsamda, öncelikle değişkenlerin birim kök yani durağanlık özellikleri araştırılmıştır. Çalışmada değişkenlerin birim kök özellikleri Genişletilmiş Dickey-Fuller (ADF) ve Phillips-Perron (PP) birim kök testleri ile incelenmiştir. Çalışmada kullanılan değişkenler için yapılan birim kök 
testlerine ait bulgular Tablo 1'de özetlenmiştir. Tüm değişsenlerin hem ADF hem de PP birim kök testlerinde birinci dereceden farkı alındıklarında durağan hale geldikleri görülmektedir.

Tablo 1

Birim Kök Testi Sonuçları

\begin{tabular}{l|ll|ll}
\hline & \multicolumn{2}{c|}{ ADF birim kök testi - Sabitli } & \multicolumn{2}{c}{ ADF birim kök testi - Sabit ve trendli } \\
\hline Değişkenler & Test İstatistiği & Gecikme Uzunluğu & Test İstatistiği & Gecikme Uzunluğu \\
\hline DK & 3.129 & 4 & 0.647 & 4 \\
PF & -2.143 & 0 & -2.078 & 0 \\
$\Delta$ DK & $-35.734^{* * *}$ & 3 & $-35.929^{* * *}$ & 3 \\
$\Delta$ PF & $-72.082^{* * *}$ & 0 & $-72.079^{* * *}$ & 0 \\
\hline \multicolumn{1}{c|}{ PP birim kök testi - Sabitli } & PP birim kök testi - Sabit ve trendli \\
\hline \multicolumn{1}{c|}{ Değişsenler } & Test İstatistiği & Bandwidth & Test İstatistiği & Bandwidth \\
\hline DK & 2.863 & 32 & 0.415 & 32 \\
PF & -2.250 & 20 & -2.195 & 20 \\
$\Delta$ DK & $-63.999^{* * *}$ & 35 & $-63.934^{* * *}$ & 39 \\
$\Delta \mathrm{PF}$ & $-72.237^{* * *}$ & 20 & $-72.232^{* * *}$ & 20 \\
\hline
\end{tabular}

Not. Maksimum gecikme uzunluğu 12 olarak alınmıştır. ADF testinde gecikme uzunluklarının belirlenmesinde ve model seçiminde Schwartz Bilgi Kriteri kullanılmıştır. PP testi Bandwidth genişliği Bartlett - Kernel methodu ile belirlenmiştir. ***, $\% 1 * *, \% 5$ ve *, $\% 10$ istatistiksel anlamlılık düzeylerini göstermektedir. Bu düzeyler için kritik değerler sabitli model için sırasıyla $-3.41,-2.862$ ve -2.567 ; sabitli ve trendli model için $-3.960,-3.411$ ve -3.127 'dir.

Değişkenlerin durağanlık özellikleri araştırıldıktan sonra, nominal döviz kuru ve petrol fiyatları arasındaki nedensellik ilişkisi araştırılmıştır. Bu kapsamda, Hacker ve Hatemi-J (2006) tarafından geliştirilen Bootstrap Temelli Toda-Yamamoto simetrik nedensellik testi sonuçları Tablo 2'de sunulmuştur. Simetrik nedensellik analizden elde edilen bulgulara göre, incelenen dönemde döviz kuru ve petrol fiyatları arasında karşılıklı bir nedensellik ilişkisi olduğu görülmüştür. Buna göre döviz kurunun petrol fiyatlarının istatistiksel olarak \%1 anlamlılık düzeyinde nedeni olduğunu, petrol fiyatlarının ise döviz kurunun istatistiksel olarak \%10 anlamlılık düzeyinde nedeni olduğunu ifade edilebiliriz.

Tablo 2

Hacker ve Hatemi-J (2006) Bootstrap Temelli Toda-Yamamoto Nedensellik Testi Sonuçları

\begin{tabular}{|c|c|c|c|c|c|}
\hline \multirow[t]{2}{*}{ Yokluk Hipotezi } & \multirow[t]{2}{*}{ Test İstatistiği } & \multirow[t]{2}{*}{ Gecikme } & \multicolumn{3}{|c|}{ Kritik Değerler } \\
\hline & & & $\% 1$ & $\% 5$ & $\% 10$ \\
\hline $\mathrm{DK} \nRightarrow \mathrm{PF}$ & $30.361 * * *$ & 1 & 15.995 & 11.374 & 9.228 \\
\hline $\mathrm{PF} \nRightarrow \mathrm{DK}$ & $10.992 *$ & 1 & 16.582 & 11.261 & 9.308 \\
\hline
\end{tabular}


Simetrik nedensellik analizinden farklı olarak çalışmada Hatemi-J (2012) tarafindan geliştirilen asimetrik nedensellik testi kullanılmış ve elde edilen bulgulat Tablo 3 'te sunulmuştur. $\mathrm{Bu}$ çerçevede, pozitif ve negatif şokların etkileri ayrı ayrı incelenerek nedenselliğin yönü tespit edilmeye çalışılmıştır. Asimetrik nedensellik testinin amacı farklı şok tiplerinin varlığında nedensellik ilişkilerinin değişkenlik gösterip göstermediğinin tespit edilmesidir ( Adıgüzel vd. 2016: 244).

Tablo 3

\section{Hatemi-J (2012) Asimetrik Nedensellik Testi Sonuçları}

\begin{tabular}{llllll}
\hline Yokluk Hipotezi & Test Istatistiği & Gecikme & \multicolumn{3}{c}{ Kritik Dĕgerler } \\
\cline { 3 - 5 } & & & \%1 & \%5 & \%10 \\
\hline$D K^{+} \nRightarrow P F^{+}$ & $19.163^{*}$ & 1 & 30.806 & 21.187 & 17.769 \\
$P F^{+} \nRightarrow D K^{+}$ & $179.081^{* * *}$ & 1 & 32.942 & 21.520 & 17.681 \\
\hline$D K^{-} \nRightarrow P F^{-}$ & $21.043^{* *}$ & 1 & 23.778 & 17.407 & 14.895 \\
$P F^{-} \nRightarrow F K^{-}$ & $52.753^{* * *}$ & 1 & 23.654 & 17.472 & 14.925 \\
\hline
\end{tabular}

Not. Gecikme uzunlukları Hatemi-J Bilgi Kriterine göre belirlenmiştir. ***, ** ve * sırasılyla \%1, \%5 ve \%10 istatistiksel anlamlılık düzeylerini göstermektedir. Kritik değerler 10000 tekrarlı bootstrap dağılımından elde edilmiştir.

Asimetrik nedensellik testinden elde edilen bulgulara göre, hem pozitif hem de negatif bileşenlerde petrol fiyatlarından döviz kuruna doğru istatistiksel olarak \%1 anlamlılık düzeyinde bir nedensellik olduğu görülmektedir. Diğer taraftan, pozitif bileşenlerde döviz kurundan petrol fiyatlarına doğru nedensellik istatistiksel olarak \%10 anlamlılık düzeyinde söz konusu iken, negatif bileşenlerde döviz kurundan petrol fiyatlarına doğru nedensellik istatistiksel olarak \%5 anlamlılık düzeyinde söz konusudur.

\section{Sonuç}

Bu çalışmada nominal döviz kuru ile petrol fiyatları arasındaki ilişki Türkiye ekonomisi için asimetrik ve simetrik nedensellik testleri ile incelenmektedir. Simetrik nedensellik analizden elde edilen bulgulara göre, incelenen dönemde döviz kuru ve petrol fiyatları arasında karşılıklı bir nedensellik ilişkisi olduğu görülmüştür. Asimetrik nedensellik testinden elde edilen bulgulara göre, hem pozitif hem de negatif bileşenlerde petrol fiyatlarından döviz kuruna doğru bir nedensellik olduğu görülmektedir. Petrol fiyatlarından döviz kuruna doğru bir nedensellik ilişkisinin var olması petrol ithalatçısı olan Türkiye için beklenen bir sonuç olarak karşımıza çıkmaktadır. Ayrıca ilişki asimetrik niteliktedir. Nedensellik ilişkisinin hem negatif hem de pozitif petrol fiyatı şoklarından döviz kuru şoklarına doğru olduğu görülmüştür. Sonuçlar incelenen dönemde petrol fiyatlarının 
Türkiye gibi gelişmekte olan bir ülkenin döviz kurları üzerinde etkili olduğunu göstermektedir. Bu ilişkilerin bilinmesi petrol fiyatı ve döviz kuru hareketlerinden kaynaklanan ani ve önemli şokları önlemek için hükümet politikasının geliştirilmesinde politika yapıcılar için bir rehber niteliği taşımaktadır.

\section{Kaynakça}

Adıgüzel, U., Kayhan, S., \& Bayat, T. (2016). Petrol Fiyatları ve Döviz Kuru Arasındaki İlişkinin Ampirik Analizi: Asimetrik Nedensellik Analizi. Cumhuriyet Üniversitesi İktisadi ve İdari Bilimler Dergisi, 17(2), 241-252.

Ağazade, S. (2018). Reel Döviz Kuru ve Petrol Fiyatları İlişkisinde Asimetri: Azerbaycan Örneğinde Bir İnceleme. Uluslararası İktisadi ve İdari Incelemeler Dergisi, 113-126.

Altıntaş, H. (2013). Türkiye'de Petrol Fiyatları, İhracat ve Reel Döviz Kuru İlişkisi: ARDL Sınır Testi Yaklaşımı ve Dinamik Nedensellik Analizi. Uluslararası Yönetim İktisat ve İşletme Dergisi, 9(19), 1-30.

Bal, D. P., \& Rath, B. N. (2015). Nonlinear Causality Between Crude Oil Price and Exchange Rate: A Comparative Study of China and India. Energy Economics, 51, 149-156.

Büberkökü, Ö. (2021). Reel Efektif Döviz Kurları ile Reel Petrol Fiyatları Arasındaki Nedensellik İlişkisinin Analizi. Igdir University Journal of Social Sciences, 26, 290-313.

Chen, S. S., \& Chen, H. C. (2007). Oil Prices And Real Exchange Rates. Energy Economics, 29(3), 390-404.

Dücan E. \& Şentürk M. (2017). Döviz Kuru ve Petrol Fiyatı İlişkisi: Küresel Finans Krizi Sonrası Deneyimler, Ed. (Koç et al), Dünden Bugüne Ekonomi Yazıları, Küv Yayınları, 28-46.

Fasanya, I. O., Oyewole, O. J., \& Raheem, I. D. (2021). Oil Prices and Exchange Rate Dynamics: How Important Is the Role of Asymmetry and Structural Breaks?. Journal of African Business, 1-20.

Granger, C. W., \& Yoon, G. (2002). Hidden cointegration. U of California, Economics Working Paper, (2002-02).

Hacker, R. S., \& Hatemi-J, A. (2006). Tests For Causality Between Integrated Variables Using Asymptotic and Bootstrap Distributions: Theory and Application. Applied Economics, 38(13), 1489-1500.

Hatemi-j, A. (2012). Asymmetric Causality Tests With An Application. Empirical Economics, 43(1), 447-456.

Huang, B. N., Lee, C. C., Chang, Y. F., \& Lee, C. C. (2020). Dynamic Linkage Between Oil Prices and Exchange Rates: New Global Evidence. Empirical Economics, 1-24.

Golub, S. S. (1983). Oil Prices and Exchange Rates. The Economic Journal, 93(371), 576-593. 
Gül L., Doğan N., \& Berument H. (2021). Petrol Fiyatlar1, Döviz Kuru Rejimi ve Rusya Ekonomisi, İstanbul Gelişim Üniversitesi Sosyal Bilimler Dergisi, 8 (1), 167-180.

Kisswani, K. M., Harraf, A., \& Kisswani, A. M. (2019). Revisiting the Effects of Oil Prices on Exchange Rate: Asymmetric Evidence From The ASEAN-5 Countries. Economic Change and Restructuring, 52(3), 279-300.

Krugman, P. (1983). Oil and the Dollar," in Jagdeep S. Bahandari and Bulford H. Putnam (ed.). Economic Interdependence and Flexible Exchange Rates, MIT Press, Cambridge.

Lv, X., Lien, D., Chen, Q., \& Yu, C. (2018). Does Exchange Rate Management Affect The Causality Between Exchange Rates and Oil Prices? Evidence From Oil-Exporting Countries. Energy Economics, 76, 325-343.

Öztürk, M., \& Çavdar, S. C. (2021). The Contagion of Covid-19 Pandemic on The Volatilities of International Crude Oil Prices, Gold, Exchange Rates and Bitcoin. The Journal of Asian Finance, Economics and Business, 8(3), 171-179.

Reboredo, J. C. \& Rivera-Castro, M. A. (2013). A Wavelet Decomposition Approach to Crude Oil Price and Exchange Rate Dependence. Economic Modelling, 32, 42- 57.

Robert A. Amano \& Simon van Norden, (1998). Exchange Rates and Oil Prices, Review of International Economics, 6 (4), ss.683-694.

S. Brock Bloomberg \& Ethan S. Harris (1995). The Commodity-Consumer Price Connection: Fact Or Fable ?, Federal Reserve Board of New York Economic Policy Review, 1(3), ss.21-38.

Tiwari, A. K., \& Albulescu, C. T. (2016). Oil Price and Exchange Rate in India: Fresh Evidence From Continuous Wavelet Approach and Asymmetric, Multi-Horizon Granger-Causality Tests. Applied Energy, 179, 272-283.

Toda, H. Y., \& Yamamoto, T. (1995). Statistical Inference In Vector Autoregressions with Possibly Integrated Processes. Journal of Econometrics, 66(1-2), 225-250.

Yaylalı, M., \& Lebe, F. (2012). İthal Ham Petrol Fiyatlarının Türkiye'deki Makroekonomik Aktiviteler Üzerindeki Etkisi. Marmara Üniversitesi Iktisadi ve İdari Bilimler Dergisi, 32(1), 43-68.

Yilmaz, A., \& Altay, H. (2016). Examining the Cointegration Relationship and Volatility Spillover Between Imported Crude Oil Prices and Exchange Rate: The Turkish Case. Ege Academic Review, 16(4), 655-671. 